\title{
Internalisasi Toleransi pada Lembaga Pendidikan (Studi Kasus di SMKN 1 Grogol Kediri)
}

\author{
Mohammad Irmawan Jauhari \\ Sekolah Tinggi Agama Islam \\ MAARIF Kendal Ngawi
}

Email : irmawan_jauhari@gmail.com

\begin{abstract}
Abstrak
Penelitian tentang internalisasi toleransi pada lembaga pendidikan penting dilakukan sebagai salah satu cara deradikalisasi kaum muda dan membuat mereka lebih toleran terhadap sesama. Internalisasi toleransi jika dilihat dari taksonomi Bloom memberikan gambaran di wilayah kognitif, afektif, dan psikomotorik. Hasil penelitian menyebutkan, domain kognitif siswa SMKN 1 Grogol Kediri terkait materi toleransi, mereka memiliki basic kognitif yang baik dikarenakan proses pembelajaran yang baik dan memiliki bekal pengalaman bertoleransi dalam lingkungan yang majemuk. Domain afektif, para guru memberikan pengakuan terhadap siswa akan rasa nyaman pada minoritas, sehingga semua murid dengan latar belakang yang berbeda (horisontal dan vertikal) bisa berkembang menjadi lebih baik. Domain psikomotorik mengedepankan adanya pembiasaan dan keteladanan. Siswa SMKN 1 Grogol Kediri dibiasakan untuk bertoleransi, menghargai perbedaan, dan mendapatkan keteladanan dari para gurunya. Baik ketika bergaul dengan sesama maupun dengan orang lain. Sebagai rekomendasi penelitian yang akan datang, bullying merupakan persoalan tersendiri. Di satu sisi ia jelas sikap anti toleran, namun di sisi lain, ia adalah bentuk pergaulan para siswa.
\end{abstract}

Kata kunci: internalisasi, toleransi, afektif, perbedaan

\section{Abstract}

Research on internalizing tolerance in educational institutions is important as one way to de-radicalize young people and make them more tolerant of others. Internalization of tolerance when viewed from Bloom's taxonomy provides an overview in the cognitive, affective, and psychomotor areas. The results of the study mentioned, the cognitive domain of students at SMK 1 Grogol Kediri related to tolerance material, they have a good cognitive basis because of a good learning process and have a stock of tolerant experiences in a plural environment. In the affective domain, teachers give recognition to students about being comfortable with the minority, so that all students with different backgrounds (horizontal and vertical) can develop better. The psychomotor domain emphasizes habit and 
exemplification. Students of SMK 1 Grogol Kediri are accustomed to tolerating, respecting differences, and getting an example from their teachers. Good when hanging out with others and with others. As a recommendation for future research, bullying is a problem in itself. On the one hand he is clearly anti-tolerant, but on the other hand, he is a form of association of students. internalization, tolerance, affective, difference

Keywords: internalization, tolerance, affective, difference

\section{PENDAHULUAN}

Sekolah sebagai bentuk lembaga pendidikan formal adalah wadah yang baik dalam melakukan internalisasi toleransi melalui serangkaian proses dalam kegiatan intrakurikuler maupun ekstrakurikuler. Internalisasi dalam proses pembelajaran jika menggunakan taksonomi Bloom, mengarah pada kognitif, afektif, dan psikomotorik. Istilah "Cognitive" berasal dari kata cognition yang padanannya knowing, berarti mengetahui. Cognition (kognisi) ialah perolehan, penataan, dan penggunaan pengetahuan. ${ }^{1} \mathrm{WS}$ Winkel menyatakan, psikologi kognitif merupakan salah satu cabang dari psikologi umum dan mencakup studi ilmiah tentang gejala-gejala kehidupan mental/psikis sejauh berkaitan dengan cara berpikir manusia, seperti terwujud dalam memperoleh pengetahuan, mengolah aneka kesan, yang masuk melalui penginderaan, menghadapi masalah/problem untuk mencari suatu penyelesaian, serta menggali dari ingatan pengetahuan dan prosedur kerja yang dibutuhkan dalam menghadapi tuntutan hidup sehari-hari. ${ }^{2}$

Afektif adalah masalah yang berkenaan dengan emosi, berkenaan dengan ini terkait dengan suka, benci, simpati, antipati, dan lain sebagainya. $^{3}$ Ranah afektif mencakup tujuan-tujuan yang berhubungan dengan sikap, nilai, perasaan, dan minat. Domain psikomotor seorang anak tidak terlepas dari kecakapan kognitif dan juga banyak terikat dengan kecakapan afektif. Karena keberhasilan pengembangan ranah kognitif juga akan berdampak positif terhadap ranah perkembangan ranah psikomotorik. ${ }^{4}$ Kecakapan kognitif berpengaruh besar terhadap berkembangnya kecakapan psikomotor. Siswa yang berprestasi baik dalam bidang pelajaran agama misalnya sudah tentu akan lebih rajin beribadah salat, puasa dan mengaji. Dia juga tidak akan segan-segan memberi pertolongan pada orang yang

${ }^{1}$ Muhibbin Syah, Psikologi pendidikan dengan Pendekatan baru, (Bandung:Remaja Rosdakarya, 2005), 66.

2 WS Winkel, Psikologi Pengajaran, (Jogjakarta: Media Abadi, 2009), 119. Lihat juga Abin Syamsuddin Makmun, Psikologi Pendidikan: Perangkat Sistem Pengajaran Modul, (Bandung: Remaja Rosdakarya, 1998), 72.

${ }^{3}$ Haidar Putra Daulay, Pendidikan Islam, (Jakarta: Kencana, 2004), 41.

${ }^{4}$ Muhibbin Syah, Op.Cit. 54. 
memerlukan. Sebab, ia merasa memberi bantuan itu adalah kebajikan (afektif), sedangkan perasaan yang berkaitan dengan kebajikan tersebut berasal dari pemahaman terhadap materi pelajaran agama yang ia terima dari gurunya (kognitif). ${ }^{5}$

Sekolah Menengah Kejuruan Negeri 1 Grogol Kabupaten Kediri yang untuk selanjutnya disingkat SMKN 1 Grogol, merupakan lembaga pendidikan yang tergolong majemuk atau multikultural. Latar belakang para murid yang ada di sana beragam. Baik dari sisi agama, aliran keagamaan, strata ekonomi, budaya, tingkat pendidikan orang tua, dan lain sebagainya. Guru yang mengajar dan staff di SMKN 1 Grogol juga beragam. Dalam lembaga tersebut tidak hanya terdiri dari satu ragam suku bangsa dan agama. Ada murid dari kalangan Islam, Nasrani, dan Hindu. Demikian suku bangsa yang ada, tidak hanya Jawa. $^{6}$ Realitas multikultural tidak menghalangi SMKN 1 Grogol Kediri untuk bergerak maju. Periode kepengurusan OSIS tahun 2016-2017 merupakan keadaan yang bisa dikategorikan multikultural. Mengingat ada perwakilan dari siswa Nasrani, dan Hindu. Masing-masing bahu membahu menyukseskan program kerja OSIS dengan baik. ${ }^{7}$ Sekolah juga memberikan kelonggaran kepada siswa pemeluk agama selain Islam untuk melaksanakan peringatan hari besar agamanya.

Toleransi di SMKN 1 Grogol mewujud dalam beberapa bentuk, menghormati orang lain yang berbeda agama, strata ekonomi, gender, dan pilihan ormas yang diikuti. Saling menghargai, saling memberikan kebebasan untuk orang lain (berpendapat, dan menyampaikan gagasannya, serta kebebasan untuk merayakan hari besar keagamaannya). ${ }^{8}$ Toleransi seperti ini tidak bisa hadir sendiri. Tentunya ada upaya-upaya yang mencoba menanamkan, memberikan pemahaman, sampai pada akhirnya bagaimana sikap tasamuh itu menjadi sebuah budaya, khususnya di SMKN 1 Grogol Kediri. Artikel ini ingin mengkaji bagaimana internalisasi di wilayah domain kognitif, bagaimana internalisasi di wilayah domain afektif, dan bagaimana internalisasi toleransi di wilayah domain psikomotorik pada siswa SMKN 1 Grogol Kediri.

${ }^{5} \mathrm{Ibid}, 54$.

${ }^{6}$ (W/01/Kediri, Rabu 11 Oktober 2017). (DO/PROLEM/2018).

7 (W/02/ Kediri, 4 Oktober 2017). Salah satu misalnya adalah, kegiatan Idhul Adha, siswa Nasrani yang menjadi pengurus OSIS turut membantu. Beberapa kegiatan lain semisal PHBN dan PHBA, mereka melakukan kerjasama dengan baik

${ }^{8}$ (W/S3/DOKO/2018) 


\section{METODE PENELITIAN}

Berdasarkan fokus dan tujuan penelitian, maka penelitian ini merupakan kajian yang mendalam guna memperoleh data yang lengkap dan terperinci. Penelitian ini bertujuan untuk mendapatkan gambaran mendalam mengenai problematika karya ilmiah dosen dan solusi perbaikannya. ${ }^{9}$ Pendekatan kualitatif menurut Best, seperti yang dikutip Sukardi adalah metode penelitian yang berusaha menggambarkan dan menginterpretasikan objek sesuai dengan apa adanya. ${ }^{10}$ Pendekatan kualitatif dipilih karena mampu mendeskripsikan sekaligus memahami makna yang mendasari tingkah laku partisipan, mendiskripsikan latar dan interaksi yang kompleks, eksplorasi untuk mengidentifikasi tipe-tipe informasi, dan mendeskripsikan fenomena. ${ }^{11}$ Jenis penelitian ini menggunakan rancangan studi kasus, ${ }^{12}$ yaitu berusaha mendeskripsikan suatu latar, objek atau peristiwa tertentu secara rinci dan mendalam. Studi kasus adalah penelitian yang bertujuan untuk mempelajari secara intensif mengenai unit sosial tertentu, yang meliputi individu, kelompok, lembaga dan masyarakat. ${ }^{13}$

Data dalam penelitian ini berarti informasi atau fakta yang diperoleh melalui pengamatan atau penelitian di lapangan yang bisa dianalisis dalam rangka memahami sebuah fenomena atau untuk men-support sebuah teori. ${ }^{14}$ Pengambilan data dalam penelitian ini dengan cara snowball sampling. Yaitu informan kunci akan menunjuk orang-orang yang mengetahui masalah yang akan diteliti untuk melengkapi keterangannya dan orangorang yang ditunjuk dan menunjuk orang lain bila keterangan kurang memadai begitu seterusnya. ${ }^{15}$ Sumber data dalam penelitian ini dapat dibedakan menjadi dua, yaitu manusia (human) dan bukan manusia. Sumber

${ }^{9}$ Muhadjir mencatat ada lima tahapan perkembangan pemikiran dalam mencari metodologi penelitian kualitatif; 1) Model Interpretif Geertz; 2) Model Grounded Research; 3) Model Ethnographik-Ethnometodologik; 4) Model Paradigma Naturalistik; dan 5) Model Interaksi Simbolik. Lihat Noeng Muhadjir, Metodologi Keilmuan: Paradigma Kualitatif, Kuantitatif, dan Mixed, (Yogyakarta: Rake Sarasin, 2007), 136-195.

${ }^{10}$ Sukardi, Metode Penelitian Pendidikan: Kompetensi dan Prakteknya, (Jakarta: Bumi Aksara, 2005), 157. YA3, 1990), 22

11 Sanapiah Faisal, Penelitian Kualitatif: Dasar-Dasar dan Aplikasi, (Malang:

12 John W. Creswell membagi lima jenis pendekatan kualitatif. Ada studi naratif, grounded, fenomenologi, etnografi, dan studi kasus. Lih, John W. Creswell, Penelitian Kualitatif dan Desain Riset:Memilih diantara lima pendekatan, (Jogjakarta: Pustaka Pelajar, 2014), 96-149.

${ }^{13}$ Yatim Riyanto, Metodologi Penelitian Pendidikan, (Surabaya : SIC, 2001), 24.

14 Jack. C. Richards, Longman Dictionary of Language Teaching and Appied Linguistics, (Kualalumpur: Longman Group, 1999), 96.

${ }^{15}$ W. Mantja, Etnografi Desain Penelitian Kualitatif dan Manajemen Pendidikan, (Malang: Winaka Media, 2003), 7. 
data manusia berfungsi sebagai subjek atau informan kunci (key informant) dan data yang diperoleh melalui informan berupa soft data (data lunak). Sedangkan sumber data bukan manusia berupa dokumen yang relevan dengan fokus penelitian, seperti gambar, foto, catatan atau tulisan yang ada kaitannya dengan fokus penelitian. Data yang diperoleh melalui dokumen bersifat hard data (data keras). ${ }^{16}$ Sumber data berupa orang, peristiwa, lokasi, dan dokumen, maka untuk dapat memperoleh data secara holistic dan integrative, pengumpulan data dalam penelitian ini menggunakan tiga teknik yaitu: wawancara mendalam (indepth interview); observasi partisipan (partisipant observation); dan studi dokumentasi (study document).

Peneliti dalam teknik analisis data selain menganalisis juga melakukan interpretasi terhadap data yang berupa kata-kata, peristiwa, dokumentasi, dan lokasi, sehingga diperoleh makna (meaning). Karena itu analisis dilakukan bersama-sama dengan proses pengumpulan data serta setelah data terkumpul. Menurut Miles dan Huberman, bahwa analisis data penelitian kualitatif dapat dilakukan melalui tiga alur kegiatan yang terjadi secara bersamaan dalam proses pengumpulan data yaitu: kondensasi data (data condensation), penyajian data (data displays dan penarikan kesimpulan/verifikasi (conclusion drawing/veriffication). Data condensation refers to the process of selecting, focusing, simplifying, abstracting, and/or transforminf the data that appear in the full corpus (body) of written-up field notes, interview trnascripts, documents, and other empirical materials. By condensing, we're making data stronger. ${ }^{17}$ Kondensasi data, sebagai langkah penyempurnaan dari reduksi data dengan demikian sifatnya lebih berusaha memampatkan data, mematangkan, menggabungkan, dan menjembatani data-data yang dalam proses reduksi data terbuang. Karena tidak ada data yang tidak penting dalam langkah kondensasi. Mengingat data yang ada dalam penelitian sudah berbasis fokus penelitian. Data itu bisa diperkuat dengan teori lain yang semakin mematangkan analisis peneliti dalam melakukan penelitian. Sebagaimana ditegaskan oleh Miles dan Huberman, ${ }^{18}$ bahwa penyajian data dimaksudkan untuk menemukan pola-pola yang bermakna serta memberikan kemungkinan adanya penarikan kesimpulan dan pengambilan tindakan. Penyajian data dalam penelitian ini juga dimaksudkan untuk menemukan

${ }^{16}$ Soft data senantiasa dapat diperhalus, diperinci dan diperdalam, karena masih selalu dapat megalami perubahan. Sedangkan hard data adalah data yang tidak mengalami perubahan lagi. Lihat dalam S. Nasution, Metode Penelitian Naturalistik Kualitatif, (Bandung: Tarsito, 2003), 55

${ }^{17}$ Matthew B. Miles, A. Michael Huberman, Qualitative Data Analysis A Mehods Sourcebook, ed 3, ( LA: Sage, 2013), 8

${ }^{18}$ Ibid, 22 
suatu makna dari data-data yang telah diperoleh, kemudian disusun secara sistematis, dari bentuk informasi yang kompleks menjadi sederhana namun selektif. Kegiatan analisis pada tahap ketiga adalah menarik kesimpulan dan verifikasi. Sejak pengumpulan data peneliti berusaha mencari makna atau arti dari simbol-simbol, mencatat, keteraturan pola, penjelasan-penjelasan, dan alur sebab akibat yang terjadi. Dari kegiatan ini dibuat simpulansimpulan yang sifatnya masih terbuka, umum, kemudian menuju ke yang spesifik/rinci. Kesimpulan final diharapkan dapat diperoleh setelah pengumpulan data selesai.

\section{PEMBAHASAN}

\section{Domain Kognitif}

Berdasarkan hasil wawancara dan observasi, terkait wilayah kognitif siswa tentang pemahaman toleransi yang merujuk pada enam tingkatan domain kognitif, didapat data-data sebagai berikut. Pemahaman siswa tentang toleransi, diawali dari ingatan siswa akan materi toleransi itu sendiri. Mengingat dalam proses memahami dibutuhkan terlebih dahulu kuatnya ingatan. Dan ingatan itu diawali dari pembelajaran atau penyampaian materi toleransi. Beberapa informan menyatakan bila, toleransi adalah sikap peduli kepada semua orang, tidak membeda-bedakan teman, menolong sesama teman saat ada kesulitan. ${ }^{19}$ Toleransi merupakan sikap yang tidak membeda-bedakan teman ataupun seseorang dari agama, ras, suku, maupun derajat mereka. Sehingga orang yang toleran selalu memandang orang lain sama dengan dirinya sendiri. ${ }^{20}$ Toleransi menurut saya adalah rasa menghargai dan peduli kepada sesama meskipun ada perbedaan ${ }^{21}$ toleransi menurut saya adalah rasa saling menghargai, menghormati sesama manusia atau tidak membeda-bedakan teman, ${ }^{22}$ toleransi menurut saya adalah rasa kepedulian terhadap sesama. ${ }^{23}$ Toleransi merupakan sikap kepekaan diri terhadap keadaan, misalkan ketika kita mempunyai teman yang beda agama sebaiknya kita bertoleransi dan menghargai mereka serta berusaha bergaul dengan akrab. Agar jika kita melihat atau barangkali mengetahui ada seseorang yang memerlukan bantuan maka harus membantu. ${ }^{24}$

Penerapan toleransi di SMKN 1 Grogol Kediri perlu dilihat secara utuh meskipun dalam wilayah kognitif yang dilihat terlebih dahulu adalah

${ }^{19}$ (W/05/Kamis 8 November 2018)

${ }^{20}$ (W/06/Kamis 8 November 2018)

${ }^{21}(\mathrm{~W} / 07 /$ Kamis 8 November 2018)

22 (W/08/Kamis 8 November 2018)

23 (W/09/8 November 2018)

24 (W/10/ 8 November 2018) 
kemampuan siswa dalam menjelaskan toleransi. Beberapa informan menyatakan bila, penerapan toleransi mengambil banyak bentuk, seperti kerja sama dalam kerja bakti di sekolah, saling bekerjasama, saling membantu, kerja kelompok dalam mengerjakan tugas, tetap menghargai dan tidak membeda-bedakan atau memilih teman dalam bergaul. ${ }^{25}$ Praktik toleran di sekolah dimulai dari lingkungan kelas dengan membuat kelompok diskusi yang tidak membeda-bedakan siswa karena kelas kita ada orang yang non muslim juga. Lalu dengan adanya kegiatan kerja bakti yang menambah sikap saling toleran antar sesama siswa dengan saling tolong menolong dalam kegiatan apapun. ${ }^{26}$ Praktik toleransi secara sederhana bisa dilihat dari adanya pemberian kesempatan teman untuk mengajukan pendapat dalam kelompok, ${ }^{27}$ toleransi dapat dilakukan kepada siapa saja yang ada di sekolah, terutama kepada sesama teman, contohnya adalah memberi kebebasan teman berbicara ketika diskusi kelompok. ${ }^{28}$ Salah satu bentuk penerapan toleransi adalah sikap saling menghormati antara sesama teman, antara guru dan murid, contohnya adalah, kita menghargai guru dengan cara kita bicara dengannya, atau ketika melihat teman kita terkena musibah, maka sebaiknya kita menolongnya. ${ }^{29}$

Pemahaman siswa mengenai toleransi didukung oleh materi yang ada dalam pembelajaran PAI dan juga terintegrasi dengan mata pelajaran lain. ${ }^{30}$ Pembelajaran yang dilakukan di dalam kelas merupakan perubahan dalam tingkah laku sebagai akibat dari interaksi antara stimulus dan respon, ${ }^{31}$ dengan demikian pembelajaran lebih memberikan penekanan kepada hasil dan tidak semata proses. Pembelajaran sebagai bagian dari internalisasi toleransi memberikan porsi penting dalam domain kognitif dalam rangka memberikan dasar pijakan yang jelas bagi siswa mengenai apa sebenarnya toleransi, mengapa penting, dan bagaimana penerapannya dalam kehidupan. Lingkungan pembelajaran yang dalam hal ini sekolah juga penting sebagai bagian dari proses membentuk perilaku dalam artian,

25 (W/07/Kamis 8 November 2018)

${ }^{26}$ (W/08/Kamis 8 November 2018)

${ }^{27}$ (W/09/ 8 November 2018)

28 (W/10/ 8 November 2018)

29 (W/11/ 8 November 2018)

${ }^{30}$ Kondisi ini dalam perspektif PBL( Problem Based Learning) cukup tepat untuk mengembangkan potensi siswa, dimana murid merasa aman dan diterima, diberi kesempatan untuk mengkonfrontasikan informasi baru atau pemahaman baru yang didapat dari lingkungan dan sumber lain, sehingga dengan diskusi yang baik, siswa dapat memperoleh makna dari pembelajaran yang dilakukan. Lihat Warsono dan Hariyanto, Pembelajaran Aktif, Teori dan Asesmen, (Bandung: Remaja Rosdakarya, 2012), 149.

${ }^{31}$ Dirman dan Cicih Juarsih, Teori Belajar dan Prinsip-Prinsip Pembelajar yang Mendidik, Seri Peningkatan Kompetensi Guru dalam rangka Implementasi Standar Proses Pendidikan Siswa, (Jakarta: Rineka Cipta, 2002), 12. 
lingkungan tempat siswa belajar, turut mendorong perubahan perilaku. Jika ingin membuat seseorang menjadi lebih toleran, tentu sekolah harus menciptakan lingkungan yang penuh dengan indikator tasamuh. Penguatan atau pelaksanaan beberapa indikator toleransi yang dilakukan berulang kali di sekolah pada akhirnya menguatakan memori siswa sehingga ingatan siswa mengenai toleransi semakin kuat dan mempengaruhi karakter mereka.

Tahap penting dari domain kognitif terakhir adalah bagaimana berdasarkan pengetahuan yang diterima, siswa bisa menciptakan, mengembangkan materi toleransi menjadi suatu hal baru dalam kehidupannya, atau menegaskan dan memperkuat bangunan toleransi yang sudah ada. ${ }^{32}$ Mengingat dalam tahap ini dibutuhkan banyak hal agar domain kognitif menjadi semakin lengkap, bisa jadi adalah adanya unsur penunjang yang bisa mendukung pemahaman siswa itu sendiri. Beberapa informan menjelaskan, sikap toleransi bisa dihadirkan dalam keseharian dengan beberapa dukungan dan pengkondisian yang ada, contohnya adalah dalam ekstra Pramuka, karena di dalam kegiatan pramuka diajarkan sikap peduli kepada sesama dan lingkungan. ${ }^{33}$ Toleransi sebenarnya bisa dilihat dari dua sikap, yakni saling menghormati dan menghargai segala perbedaan, dan untuk melakukannya, butuh dukungan semua pihak. Dalam hal ini pramuka adalah yang paling penting untuk semakin membiasakan siswa berperilaku toleran. ${ }^{34}$

Data-data dalam domain kognitif menunjukkan adanya peran penting guru dalam proses pembelajaran. Jika proses pembelajaran yang ada dipotret dengan menggunakan teori komunikasi milik Laswell, maka terdapat lima komponen penting di dalamnya yang menyebabkan domain kognitif menjadi begitu kuat. Komponen komunikasi tersebut adalah, pertama, komunikator adalah pelaku utama komunikasi. Kedua, pesan yang akan disampaikan kepada penerima. Ketiga, saluran untuk menyampaikan pesan. Keempat, penerima pesan. Kelima, efek yang terjadi pada penerima setelah menerima pesan dari sumber,seperti perubahan sikap, bertambahnya

\footnotetext{
${ }^{32}$ Untuk melihat basis kognitif sebelum sekolah, ada tiga istilah yang bisa membantu memahaminya. Ada tiga bentuk perilaku manusia, konatif, volisional, dan normatif. Perilaku konatif adalah perilaku yang tersirat memiliki tujuan, namun tidak secara sadar bertujuan. Contohnya adalah perilaku bayi. Volisional adalah perilaku konatif yang disadari dimana individu punya tujuan di benaknya. Perilaku normatif adalah perilaku yang diarahkan, secara tersirat atau gamblang oleh gagasan-gagasan tertentu yang berkaitan dengan apa yang umumnya dianggap baik atau dikehendaki. Untuk lebih jelasnya lihat William F. O'neil, Ideologi-Ideologi Pendidikan, pen. Omi Intan Naomi, (Yogjakarta: Pustaka Pelajar, 2008), 50
}

33 (W/07/Kamis 8 November 2018)

${ }^{34}$ (W/08/Kamis 8 November 2018) 
pengetahuan, dll. ${ }^{35}$ Guru dalam hal ini adalah komunikator vital dalam proses internalisasi di domain kognitif. Guru yang ada di SMKN 1 Grogol Kediri, baik guru agama, PKN, dan guru lain, memiliki peran penting untuk menanamkan toleransi agar menjadi sebuah nilai yang mengakar kuat pada siswa mereka.

Materi toleransi memang sepertinya hanya menjadi wilayah PKN dan agama, namun dalam prakteknya, semua guru secara langsung melakukan proses internalisasi tentang pentingnya toleransi dalam kehidupan bersama. Karena itulah, toleransi menjadi mengakar pada siswa SMKN 1 Grogol Kediri. ${ }^{36}$ Selain itu, faktor penunjang yang menjadikan toleransi begitu kuat adalah, sebuah kenyataan apabila latar belakang siswa yang memang tinggal di kawasan majemuk, membuat sebuah dasar kognitif mereka mengenai toleransi sudah tertata. ${ }^{37}$ Dialektika antara pengalaman keseharian siswa dengan materi toleransi dalam tataran kognitif seperti sebuah hubungan yang saling melengkapi. Guru Agama misalnya, menjelaskan dan menyampaikan dalil agama tentang pentingnya toleransi dan menjaga kerukunan dalam kehidupan sehari-hari. ${ }^{38}$ Yang mana hal tersebut semakin memperkuat apa yang dilihat dan dialami oleh siswa ketika mereka pulang dan berinteraksi dengan tetangganya. ${ }^{39}$ Pesan atau materi yang disampaikan oleh guru adalah toleransi. Jabaran toleransi sangat beragam. Terlebih semua agama mengajarkan pemeluknya untuk toleran. Tidak ada ajaran agama yang menganjurkan umatnya untuk menjadi eksklusif, kecuali beberapa aliran yang cenderung tertutup. Materi toleransi selain disampaikan oleh guru PKN, guru lain seperti PAI, PAK, dan PAH juga menguatkan sehingga siswa merasa ada muatan moral dan nuansa yang sakral karena agama mereka juga menganjurkan untuk bertoleransi.

Salah satu citra dari keberhasilan lembaga yakni bagaimana perilaku siswa itu dapat dilihat, dapat dirasakan, dan dapat diamati oleh orang tua mereka secara langsung. Apabila terjadi perubahan attitude, tentu hal tersebut akan semakin membanggakan orang tua. Karena SMKN 1 Grogol Kediri selain membuat siswa mereka pandai dalam dunia teknologi, namun tidak membuat sikap dan perilaku mereka berlebihan. ${ }^{40}$ Semua guru kemudian menjadi sebuah sarana penguat pesan akan pentingnya bersikap

\footnotetext{
${ }^{35}$ Suryanto, Pengantar Ilmu Komunikasi, (Bandung: Pustaka Setia, 2015), 160. Lihat juga, Onong Uchjana Effendy. Ilmu Komunikasi - Teori dan Praktek. (Bandung: Remaja Rosdakarya, 2006), 10.

36 (W/S1/DOKO/2018)

37 (D/PROLEM/2018)

38 (W/S4/DOKO/2018)

39 (W/S11/DOKO/2018)

${ }^{40}(\mathrm{O} / \mathrm{KOLEM} / 2018)$
} 
toleran dalam kehidupan sehari-hari. ${ }^{41}$ Tidak hanya ketika dalam masa pelajaran di kelas. Namun dalam pergaulan di lembaga, baik jam belajar maupun jam ekstra.

Saluran yang digunakan guru untuk menanamkan toleransi pada siswa di SMKN 1 Grogol Kediri bisa dilihat dari proses pembelajaran dan bimbingan mereka. Sebagian guru, terlebih guru PAI terlibat aktif dalam beberapa kegiatan ekstra. Materi Pendidikan Agama Islam ada berkaitan dengan tema toleransi. Yaitu pada kelas X. Sedangkan kelas X adalah kelas pertama dari jenjang pendidikan menengah kejuruan. Dengan diberikannya materi toleransi, tentu ada tujuan jangka pendek dan jangka panjang bagi siswa itu sendiri. Jangka pendeknya adalah, dalam kehidupan keseharian, terutama di sekolah, mereka bisa menerapkan beberapa sikap toleransi kepada anggota lembaga pendidikan tersebut.

Membuat siswa menjadi toleran tentu tidaklah mudah. Dibutuhkan dan diperlukan usaha maupun waktu yang tidak sedikit. Karenanya, beberapa guru menjadi pembimbing siswa dalam kegiatan ekstra. Pada kesempatan tersebut, guru-guru yang menjadi pembimbing ekstra menyertakan dan menyelipkan materi tentang toleransi. Sehingga, atau intrakurikuler dan ekstrakurikuler sangat berkaitan erat dengan penanaman toleransi. Bisa dikatakan juga bahwa keduanya menjadi saluran bagi para guru didalam memberikan pemahaman yang komprehensif kepada siswa mereka tentang toleransi. Siswa adalah sasaran utama dari guru dalam internalisasi toleransi di SMKN 1 Grogol Kediri. Meskipun materi toleransi sudah pernah disampaikan pada jenjang paling dasar dalam dunia pendidikan, namun materi toleransi tetap penting diberikan. Mengingat, para murid sekolah menengah adalah anak-anak yang beranjak remaja. Mereka akan memandang segala sesuatunya berdasarkan dari sudut pandang diri dan kelompoknya. Keakuan, baik personal maupun kelompok sangatlah kuat. Hal ini dibuktikan dengan adanya tayangan media tentang solidaritas anakanak pelajar, atau istilahnya geng sekolah. Dan semakin parah diproyeksikan melalui sinetron maupun film bertema kehidupan remaja sekolah menengah. Masa yang demikian tentulah membutuhkan asupan materi bagaimana menjalani hidup yang baik di tengah lingkungan yang majemuk. Di tengah lingkungan yang membutuhkan sikap saling menghargai, dan bagaimana membaut seseorang tidak selalu memandang segala sesuatunya hanya berdasarkan dirinya sendiri.

Efek atau hasil dari proses penyampaian materi toleransi dalam domain kognitif siswa sangatlah beragam. Bagi mereka yang terbiasa hidup di lingkungan multikultural, materi toleransi yang diberikan para guru

${ }^{41}$ (W/S7/KOLEM/2018) 
semakin memperteguh sikap mereka. Karena sikap dan perilaku mereka ada justifikasi. Baik dari sisi agama, maupun negara. Dengan adanya butir-butir pancasila yang menjelaskan sikap toleran. Sedangkan untuk siswa yang tinggal dalam lingkungan yang homogen, tentu toleransi dan segala dinamikanya menjadi informasi menarik yang perlu dibuktikan atau digali lebih lanjut.

\section{Domain Afektif}

Afektif mencakup segala sesuatu yang terkait dengan emosi, misalnya perasaan, nilai, penghargaan, semangat, minat, motivasi, dan sikap. Beberapa informan menyatakan, siswa bergaul di sekolah tanpa membeda-bedakan apakah teman itu seagama dengan kita atau tidak, apakah kaya atau miskin, dan seperti itu. ${ }^{42}$ Salah satu bentuk penerimaan terhadap konsep toleransi adalah memberi kesempatan teman untuk mengajukan pendapat dalam kelompok, dan itu kerap ditunjukkan dalam musyawarah kelas. ${ }^{43}$ Praktek toleransi dapat dilakukan kepada siapa saja yang ada di sekolah, terutama kepada sesama teman, contohnya adalah memberi kebebasan teman berbicara ketika diskusi kelompok. ${ }^{44}$ Sikap dan perasaan siswa terhadap teman yang berbeda, baik suku, agama, budaya, sampai strata ekonomi adalah menghargai dan tidak membeda-bedakannya, apabila terjadi pembagian kelompok untuk melakukan tuga, kami berusaha bekerjasama dengan baik. ${ }^{45}$ Perbedaan di dalam kelas maupun lembaga pendidikan adalah hal yang wajar, siswa menghormati dan menghargai (teman yang berbeda), dan bentuk kerjasama antara siswa bisa dilihat dalam pembagian jadwal piket kelas, kerjasama dalam kelompok, dan ketika mengikuti ekstra. ${ }^{46}$

42 (W/07/Kamis 8 November 2018). Observasi yang peneliti lakukan juga menunjukkan hal yang sama. Bahwa dari cara bergaul siswa SMKN 1 Grogol Kediri, tidak begitu kentara atau belum terlihat sentimen SARA muncul. Hal ini peneliti amati langsung dalam pola komunikasi, gaya bergaul, dan beberapa aktifitas lain, (Observasi, Kamis 8 November 2018).

${ }^{43}$ (W/09/Kamis 8 November 2018). Hasil wawancara ini senada dengan hasil observasi yang menunjukkan ketika musyawarah kelas terjadi, meskipun pro dan kontra terjadi, namun tetap para siswa memberi kesempatan temannya menyampaikan pendapat. Walau pendapat yang disampaikan kurang masuk akal dan menjadi bahan candaan, (observasi, Kamis 8 Oktober 2018).

${ }^{44}$ (W/10/Kamis 8 November 2018)

45 (W/08/Kamis 8 November 2018)

46 (W/11/Kamis 8 November 2018). 
Data yang ada terkait domain afeksi, akan dianalisis dengan teori kebutuhan Maslow ${ }^{47}$ mengingat domain afeksi lebih menitikberatkan pada pertimbangan emosi dan kecenderungan psikologi siswa. Dalam pembelajaran dan lingkungan sekolah, kebutuhan mendasar seorang siswa adalah adanya pengakuan. Baik dari sesama teman, guru, maupun warga sekolah lain. Ketika kebutuhan mendasarnya sudah terpenuhi, maka aktualisasi diri akan terdorong menjadi lebih baik.

Adanya pengakuan terhadap kelompok lain, siswa yang memiliki agama yang berbeda, berasal dari suku lain, berangkat dari strata ekonomi dan lingkungan geografis yang berbeda, tentu membutuhkan proses yang tidak sedikit. Pengakuan terhadap kelompok lain pada dasarnya adalah konsep toleransi pertama sebelum sikap dan bentuk toleransi lainnya. Pengakuan ini tidak mudah jika tanpa didasari pemahaman atau terpenuhinya basis kognitif siswa. Dorongan untuk mengakui kelompok lain, adalah sebuah gejala positif sebagai langkah awal toleransi. Dengan mengakui bahwa kelompok lain adalah sama-sama siswa yang memiliki hak dan kewajiban yang sama, maka proses pembelajaran akan berjalan dengan baik. Dengan mengakui bahwa kaum minoritas memiliki peluang yang sama dalam perkembangan dan perubahan, maka sebenarnya kaum mayoritas pada dasarnya telah menunjukkan kebesaran jiwa mereka.

Pengakuan kelompok lain tidak akan terjadi tanpa mengetahui siapakah diri sendiri. Dalam hal ini, materi-materi keagamaan maupun berkaitan dengan budaya lokal yang masuk dalam mulok juga perlu diperhatikan. Islam sebagai agama mayoritas yang dipeluk oleh siswa dan guru di SMKN 1 Grogol Kediri, melakukan penguatan-penguatan terhadap nilai-nilai keagamaan mereka. Hal yang sama juga dilakukan oleh siswa dan guru beragama Katolik serta Hindu. Siswa dan guru beragama Islam tentu menyadari posisi mereka, namun bukan berarti kemudian menyudutkan dan menganggap tidak ada dua agama lain dalam lembaga pendidikan tersebut. Kemauan untuk merangkul, menghargai, dan mengakui kelompok lain diperlukan tidak semata demi hasil pembelajaran yang baik, akan tetapi juga tujuan sekolah itu sendiri. Terlepas apapun golongan yang ada, mereka dapat bahu membahu dan bekerjasama. Saling mengisi serta menutup celah kekurangan yang ada. ${ }^{48}$

47 Teori Abraham Maslow menyatakan, bila dasar dari kebutuhan seseorang terpenuhi, maka akan mudah untuk mendorongnya maju. Dalam dunia pendidikan, kebutuhan seorang siswa bisa saja rasa nyaman, diakui sebagai anggota lembaga, dan diperlakukan dengan baik oleh anggota sekolah lain. (http://akhmadsudrajat.wordpress.com, 5 Januari 2018)

${ }^{48}$ (O/PEBOR/2018) 
Pengakuan atas yang lain ini pada nantinya akan mendorong semangat belajar yang luar biasa pada siswa dan siswi SMKN 1 Grogol Kediri. Selain itu juga dapat menciptakan iklim yang sangat harmonis, dimana pada beberapa kesempatan, ada kerjasama diantara guru dan siswa dalam hal PHBN dan PHBA. ${ }^{49}$ Siswa yang tidak yakin bahwa mereka diakui dan dicintai teman beserta gurunya, cenderung tidak memiliki kemampuan untuk berkembang. Atau bisa jadi ia akan semakin termotivasi untuk berkembang, namun arahnya negatif semisal show force agar orang lain takut kepadanya. Pada saat yang demikian, peran guru dan lingkungan sekolah menjadi penting dalam mengkonstruk domain afektif siswa.

Guru yang berhasil membuat siswa merasa senang dan membuat mereka merasa diterima dan dihormati sebagai individu, lebih besar peluangnya untuk membantu mereka menjadi bersemangat untuk belajar demi pembelajaran dan kesediaan berkorban untuk menjadi kreatif dan terbuka terhadap ide-ide baru. Apabila siswa dikehendaki menjadi pelajar yang mandiri, mereka harus yakin bahwa guru akan merespon secara adil dan konsisten kepada siswa. Dengan dukungan lingkungan sekolah yang toleran dan terbuka, maka akan dapat terpenuhi kebutuhan mendasar siswa sebagai modal awal mengembangkan potensi mereka.

\section{Domain Psikomotorik}

Ranah Psikomotorik meliputi gerakan dan koordinasi jasmani, keterampilan motorik dan kemampuan fisik. Ketrampilan ini dapat diasah jika sering melakukannya. Wujud nyata hasil psikomotor dari materi toleransi yang merupakan kelanjutan dari hasil belajar kognitif dan afektif itu sendiri. Beberapa informan menyatakan, melalui pembelajaran kami tegaskan apabila toleransi dimulai dari perilaku umat Islam itu sendiri, bagaimana mereka berinteraksi dengan sesama Islam, dengan non Islam, dan dengan seluruh lapisan masyarakat. ${ }^{50}$ Salah satu bentuk toleransi yang sering tampak dan sering dilakukan adalah saling menghormati sesama teman selama pergaulan, guru, dan juga kepada anggota sekolah lain. ${ }^{51}$ Sikap siswa dalam pergaulan selama di sekolah adalah saling menghormati terlebih kepada guru, ${ }^{52}$ dalam pergaulan siswa saling menghargai, dan itu ditunjukkan melalui sikap keseharian, terlebih kepada guru dan kepala

49 Th 2017, ketika idul Adha, siswa Nasrani membantu prosesi pembagian daging qurban. Siswa muslim silaturahmi ke guru dan temannya yang merayakan natal dan galungan. OSIS mengakomodir kegiatan tersebut.(W/02/Kediri, 4 Oktober 2017).

${ }^{50}$ (W/03/ 19 Oktober 2018)

51 (W/05/Kamis 8 November 2018).

52 (W/06/Kamis 8 November 2018). 
sekolah. ${ }^{53}$ Siswa dalam keseharian di sekolah, menunjukkan sikap toleran, hormat dan berlaku sopan pada guru, serta kepada warga sekolah lain seperti penjaga dan kantin..$^{54}$

Siswa siswi SMKN 1 Grogol Kediri memiliki modal pengetahuan yang cukup tentang toleransi dikarenakan mereka tinggal pada kawasan multikultural. Pergaulan dalam lingkungan sosial tersebut akan mempengaruhi gaya bergaul siswa dengan temannya. Terlebih, Desa Sonorejo yang menjadi lokasi SMKN 1 Grogol juga termasuk kawasan yang multikultural. Kemampuan siswa dalam merespon materi toleransi, pada wilayah kognitif dan afektif akan direspon dalam wilayah psikomotorik melalui pembiasaan dan keteladanan. Pembiasaan menjadi penting dikarenakan dengan adanya pembiasaan, siswa merasa bahwa sikap toleransi adalah kebutuhan dalam hidup bersama. Dengan adanya keteladanan, siswa menjadi mengerti bahwa guru, dan siapapun yang menyampaikan toleransi, mereka juga melakukannya. Tidak sekedar hanya memberikan materi tanpa ada pembuktian perilaku.

Domain psikomotorik sebagai bagian dari dialektika domain kognitif dan afektif, dimana dalam internalisasi toleransi mengarah pada pembentukan sebuah habitus. ${ }^{55}$ Habitus toleransi terdiri dari sejumlah disposisi, skema tindakan atau persepsi bahwa individu telah menerimanya melalui pengalaman bermasyarakat. Melalui pengalaman tersebut, setiap individu secara perlahan-lahan menyatukan sejumlah cara berfikir, cara merasakan dan cara beraksi yang akan terlihat secara nyata dalam waktu lama. Disposisi-disposisi ini merupakan sumber praksis individu di masa yang akan datang. Habitus terbentuk tidak secara tiba-tiba tetapi melalui proses panjang berupa pengalaman-pengalaman individu ketika berinteraksi dengan dunia sosial. Habitus dibangun melalui tiga hal yaitu pendidikan keluarga, pendidikan sosial dan pendidikan sekolah. ${ }^{56}$ Toleransi yang disampaikan dalam pembelajaran kepada siswa dan dikuatkan dalam bentuk-bentuk lain di wilayah ekstrakurikuler akan membentuk sebuah habitus. Habitus mendorong siswa memproduksi kembali secara otomatis apa yang telah diterima sebelumnya. Disposisi-disposisi yang berupa skema

${ }^{53}$ (W/07/Kamis 8 November 2018).

${ }^{54}$ (W/08/Kamis 8 November 2018).

55 Teori habitus dibangun oleh Pierre Bordieu. Untuk lebih jelasnya lihat George R., Teori Sosiologi, Dari Sosiologi Klasik sampai Perkembangan Terakhir Postmodern, (Yogyakara: Pustaka Pelajar: 2012), 54, dan lihat Pierre Bourdieo, Arena Produksi Kultural, Sebuah Kajian Sosiologi Budaya, terjemahan, (Bantul: Kreasi Wacana, 2010), 45.

${ }^{56}$ Wempi, Jefri Audi, Teori Produksi Kultural: Sebuah Kajian Pustaka. Exposure - Journal of Advanced Communication, Vol.2, No.1, Februari 2012. 
persepsi dan tindakan akan menjadikan siswa memproduksi ulang pemahamannya tentang sikap tasamuh dimanapun ia berada.

Habitus atau pembiasaan memerlukan beberapa hal, antara lain adalah dorongan, isyarat, tingkah laku balas, dan ganjaran. Dorongan, yaitu rangsangan kuat dari dalam individu yang mendorongnya untuk bertingkah laku, dorongan itulah yang membuat seseorang terpaksa harus meniru tingkah laku orang lain untuk berbuat, dorongan muncul disebabkan adanya kebutuhan yang mesti terpenuhi. Dorongan yang dialami murid dapat dilihat dari kebutuhannya untuk diterima sebagai bagian dari komunitasnya. Siswa yang tinggal pada kawasan multikultural, tentu akan sangat membutuhkan dan terbiasa melakukan toleransi. Berbeda dengan siswa yang tinggal pada kawasan yang homogen. Mereka terdorong untuk toleran mengingat ada sebuah kebutuhan bersama yang harus dipenuhi.

SMKN 1 Grogol Kediri, sebagai sebuah lembaga pendidikan baru, tentu membutuhkan persatuan dan kesatuan anggota lembaganya. Kebutuhan mereka jelas, yakni bagaimana mengangkat citra lembaga pendidikan. Salah satu cara yang dilakukan adalah menciptakan iklim yang sangat toleran. Mengingat dengan munculnya rasa toleran yang tinggi, bisa mendorong siswa untuk menjadi lebih baik. Kebutuhan akan kebersamaan inilah yang menjadi dorongan tidak hanya bagi murid, namun juga para guru.

Isyarat dan tingkah laku balas memiliki kesamaan. Isyarat adalah rangsangan yang menentukan tingkah laku balas yang akan timbul, sedangkan tingkah laku balas adalah reaksi individu terhadap tingkah laku orang lain. Dalam pergaulan selama di sekolah, tentu interaksi disertai juga komunikasi dalam bentuk non verbal. Seperti memalingkan muka, menutup mulut, dan mengangkat tangan. Isyarat-isyarat yang demikian berlaku juga pada bentuk perilaku yang bisa jadi kurang toleran. Ketika perilaku kurang toleran itu muncul dari salah satu siswa, muncul isyarat yang menandakan bahwa si pelaku sebaiknya tidak melakukan hal itu. Mengingat perilaku non toleran bisa saja menimbulkan perpecahan serta balasan yang tidak enak. Baik dari seseorang maupun komunitas. Ganjaran, yakni rangsangan yang menetapkan apakah suatu tingkah laku balas akan diulang atau tidak pada kesempatan lain, dengan adanya pemberian ganjaran maka seseorang akan tahu tingkah lakunya tepat atau tidak. Ganjaran atau reward, bisa dalam bentuk pujian, apresiasi non verbal seperti mengacungkan jempol dan tepuk tangan, dan hal lainnya baik kecil maupun besar. Ganjaran ini berguna untuk semakin membumikan sikap toleran pada siswa. Respon gembira ketika mendapatkan pujian adalah hal wajar bagi manusia. Untuk para pelajar, apalagi jika yang memberikan pujian adalah teman dan guru, maka hal tersebut berdampak pada kepercayaan diri yang tinggi. Selain juga 
memotivasi dirinya untuk senantiasa menjadi lebih baik. Tentu apresiasi maupun respon positif sering dilakukan guru dan murid apabila mereka mendapati salah saatu temannya melakukan perbuatan terpuji. Biasanya, mereka akan mengingat apa yang sudah dilakukan temannya tersebut dan menceritakan kepada yang lain.

Keteladanan dalam dunia pendidikan sangat penting. Dalam Islam, keteladanan merupakan kunci untuk melakukan perubahan. ${ }^{57}$ Islam memberi panduan kepada setiap pendidik, supaya tidak hanya mampu memberi teori, tapi lebih dari itu ia dapat menjadi panutan bagi anak didiknya. Amat tercela sikap seorang pendidik yang mengajarkan suatu kebaikan, sedangkan ia sendiri tidak menerapkan dalam kehidupan sehari-harinya. Pendidik dianjurkan untuk menanamkan nilai kebaikan pada siswanya dengan cara yang baik serta mengutamakan keteladanan. ${ }^{58}$ Tidak sebatas kepada pembelajaran di dalam kelas.

Materi toleransi adalah sebuah materi tentang keterampilan hidup bersama. Tentu akan sangat penting apabila materi ini tidak sekedar diterangkan atau dijelaskan saja di dalam kelas. Namun juga perlu untuk diterapkan dalam keseharian. Ketika guru memberikan kebebasan menyuarakan pendapat tanpa memandang siapa yang berkata, mengajarkan untuk sopan kepada sesama, melerai dari perbuatan bully dan menjelaskan sikap non toleran kurang pas untuk kehidupan bermasyarakat, pada saat itulah guru melakukan keteladanan. Demikian juga ketika guru bersikap santun dengan sesama guru dan anggota sekolah lain. Selama interaksi di lembaga pendidikan, sikap guru tentulah tidak lepas dari perhatian siswa. Guru yang memiliki sikap toleran paling tinggi, menampilkan sikap demokratis, serta menyayangi siswa, pasti akan selalu diingat dan bisa jadi ingatan tersebut akan menguat ketika siswa itu justru kembali ke masyarakat.

${ }^{57}$ Beberapa ayat Qur'an yang menjadi dasar keteladanan adalah, QS al-Baqarah ayat 44 artinya, "Mengapa kamu suruh orang lain (mengerjakan) kebajikan, sedang kamu melupakan dari (kewajiban)mu sendiri, padahal kamu membaca al-Kitab (Taurat) maka tidakkah kamu berfikir." QS as-Shaf ayat 2-3 yang artinya, "Hai orang yang beriman, mengapa kamu mengatakan apa yang tidak kamu perbuat? Amat besar kebencian di sisi Allah swt bahwa kamu mengatakan apa yang tidak kamu perbuat." QS an-Nahl ayat 125 yang artinya, "Serulah ke jalan Tuhanmu (wahai Muhammad) dengan hikmah kebijaksanaan dan nasihat pengajaran yang baik, dan berbahasalah dengan mereka (yang engkau serukan itu) dengan cara yang lebih baik; sesungguhnya Tuhanmu Dia jua yang lebih mengetahui akan orang yang sesat dari jalan-Nya, dan Dia jua yang mengetahui akan orang-orang yang mendapat hidayah petunjuk."

58 Pendekatan teori belajar sosial lebih ditekankan pada perlunya conditioning (pembiasan merespon) dan imitation (peniruan), teori ini dikenalkan oleh Albert Bandura. Lih, Al Rasyidin dan Wahyudin Nur Nasution. Teori Belajar dan pembelajaran, (Medan: Perdana Publishing, 2011), 45. 


\section{KESIMPULAN}

Domain kognitif siswa SMKN 1 Grogol Kediri terkait materi toleransi sebagian besar sudah merata. Mereka memiliki dasar kognitif yang baik dikarenakan proses pembelajaran yang baik dan memiliki bekal pengalaman bertoleransi dalam lingkungan yang multikultural. Domain afektif siswa SMKN 1 Grogol Kediri mendapatkan perhatian dari para guru. Mengingat sebagai sebuah lembaga pendidikan yang baru berdiri, tentulah out put yang bermutu menjadi jaminan kepercayaan masyarakat. Para guru memberikan pengakuan terhadap para murid, rasa nyaman pada minoritas, sehingga semua murid dengan latar belakang yang berbeda (horisontal dan vertikal) bisa berkembang menjadi lebih baik. Domain psikomotorik mengedepankan adanya pembiasaan dan keteladanan. Siswa SMKN 1 Grogol Kediri dibiasakan untuk bertoleransi, menghargai perbedaan, dan mendapatkan keteladanan dari para gurunya. Baik ketika bergaul dengan sesama maupun dengan orang lain.

Masih terdapatnya bully dan siswa memanggil teman dengan sebutan yang buruk adalah sebuah tanda apabila ada celah kosong yang perlu diisi agar internalisasi toleransi berjalan maksimal. Langkah-langkah yang bisa dijadikan rujukan untuk internalisasi toleransi selanjutnya adalah, selain mengedepankan dialog, benturkan siswa pelaku bully dengan kondisi bagaimana jika seandainya dia berada dalam posisi tersebut. Bisa jadi ia melakukan bully hanya karena merasa berada dalam posisi yang lebih baik.

\section{DAFTAR PUSTAKA}

Abin Syamsuddin Makmun, 1998, Psikologi Pendidikan: Perangkat Sistem Pengajaran Modul, Bandung: Remaja Rosdakarya.

Al Rasyidin dan Wahyudin Nur Nasution, 2011, Teori Belajar dan pembelajaran, Medan: Perdana Publishing.

Dirman dan Cicih Juarsih, 2002, Teori Belajar dan Prinsip-Prinsip Pembelajar yang Mendidik, Seri Peningkatan Kompetensi Guru dalam rangka Implementasi Standar Proses Pendidikan Siswa, Jakarta:Rineka Cipta.

Effendy, Onong Uchjana. 2006. Ilmu Komunikasi - Teori dan Praktek. Bandung : Remaja Rosdakarya

George R., 2012, Teori Sosiologi, Dari Sosiologi Klasik sampai Perkembangan Terakhir Postmodern, Pustaka Pelajar: Jakarta.

Haidar Putra Daulay, 2004, Pendidikan Islam, Jakarta: Kencana.

Jack. C. Richards, 1999, Longman Dictionary of Language Teaching and Appied Linguistics, Kualalumpur: Longman Group. 
John W. Creswell, 2014, Penelitian Kualitatif dan Desain Riset:Memilih diantara lima pendekatan, Jogjakarta:Pustaka Pelajar.

Matthew B. Miles, A. Michael Huberman, 2013, Qualitative Data Analysis A Mehods Sourcebook, ed 3, LA:Sage.

Muhibbin Syah, 2005, Psikologi Pendidikan dengan Pendekatan Baru, Bandung:Remaja Rosdakarya.

Noeng Muhadjir, 2007, Metodologi Keilmuan: Paradigma Kualitatif, Kuantitatif, dan Mixed, Yogyakarta: Rake Sarasin.

Pierre Bourdieo, 2010, Arena Produksi Kultural, Sebuah Kajian Sosiologi Budaya, terjemahan, Kreasi Wacana, Bantul.

Sanapiah Faisal, 1990, Penelitian Kualitatif: Dasar-Dasar dan Aplikasi, Malang: YA3.

Suryanto, 2015, Pengantar Ilmu Komunikasi, Bandung:Pustaka Setia.

Sukardi, 2005, Metode Penelitian Pendidikan: Kompetensi dan Prakteknya, Jakarta: Bumi Aksara.

S. Nasution, 2003, Metode Penelitian Naturalistik Kualitatif, Bandung: Tarsito.

William F. O'neil, 2008, Ideologi-Ideologi Pendidikan, pen. Omi Intan Naomi, Yogjakarta:Pustaka Pelajar.

WS Winkel, 2009, Psikologi Pengajaran, Jogjakarta:Media Abadi.

W. Mantja, 2003, Etnografi Desain Penelitian Kualitatif dan Manajemen Pendidikan, Malang: Winaka Media.

Yatim Riyanto, 2001, Metodologi Penelitian Pendidikan, Surabaya : SIC. 